\title{
Solution Models Based on Symmetric and Asymmetric Information
}

\author{
Edmundas Kazimieras Zavadskas ${ }^{1,2} \mathbb{D}$, Zenonas Turskis ${ }^{1,2} \mathbb{D}$ and Jurgita Antucheviciene ${ }^{1, *(\mathbb{D})}$ \\ 1 Department of Construction Management and Real Estate, Vilnius Gediminas Technical University, \\ Sauletekio al. 11, LT-10223 Vilnius, Lithuania; edmundas.zavadskas@vgtu.lt (E.K.Z.); \\ zenonas.turskis@vgtu.lt (Z.T.) \\ 2 Laboratory of Operations Research, Institute of Sustainable Construction, \\ Vilnius Gediminas Technical University, Sauletekio al. 11, LT-10223 Vilnius, Lithuania \\ * Correspondence: jurgita.antucheviciene@vgtu.lt; Tel.: +370-5-274-5233
}

Received: 2 April 2019; Accepted: 2 April 2019; Published: 5 April 2019

\begin{abstract}
This Special Issue covers symmetry and asymmetry phenomena occurring in real-life problems. We invited authors to submit their theoretical or experimental research presenting engineering and economic problem solution models dealing with the symmetry or asymmetry of different types of information. The issue gained interest in the research community and received many submissions. After rigorous scientific evaluation by editors and reviewers, nine papers were accepted and published. The authors proposed different solution models as integrated tools to find a balance between the components of sustainable global development, i.e., to find a symmetry axis concerning goals, risks, and constraints to cope with the complicated problems. We hope that a summary of the Special Issue as provided in this editorial will encourage a detailed analysis of the papers.
\end{abstract}

Keywords: hybrid problem solution models; multiple-criteria decision-making (MCDM); hybrid MCDM; criteria weight assessment; fuzzy sets; rough sets; Z-numbers; neutrosophic numbers; Bonferroni mean (BM) operator; engineering problems; economic decisions

\section{Introduction}

An integral part of contemporary human activities is choosing the most efficient solutions and justifying the selected alternatives and judgments of selected justifying procedures. All objective measurement involves subjective judgments. Firstly, developers of plans decide which problems must be solved and which not. Model development consists of the definition of model objectives, conceptualization of the problem, translation into a computational model, and model testing, revision, and application. Theory, prior knowledge, and other inputs determine which features of a given process to highlight and which to leave out under a given set of conditions that will dictate the specification of the model. Symmetry and asymmetry phenomena occur in real-life problems. Structural symmetry and structural regularity are essential concepts in many natural and human-made objects and play a crucial role in problem solutions. Real (accurate) balance in the real world is an exceptional case [1]. It is an essential feature that facilitates model description and the decision-making process itself.

Decision-makers need to be clear and explicit about the objectives of the problem and the importance of multiple goals, benchmarking values and acceptable compromises. The existence of information asymmetry causes difficulties when achieving an optimal solution. As the asymmetric information is more important, its role is more crucial. Therefore, various solution models propose integrated tools to find a balance between components of global development, i.e., to find symmetry axes concerning goals, risks, and constraints to cope with complicated problems. When confronted 
with complex problems, a solution's problem is divided into smaller issues. The analyst then uses a method to integrate the results so that the action can be selected temporarily.

Other stakeholders should align the decision on complex and strategic issues. Moreover, decision-makers should strike a balance between objectivity and subjectivity of data [2].

Objectivity is often considered the basis for the evaluation of the knowledge society. Objectivity is a value. The objectivity, balance, and symmetry of decision-making emphasize paradoxes [3] in terms of groups and outcomes. Science is objective when setting and summarizing facts. It is an obvious way of dealing with the requirements of scientific realism.

Confirmation of objectivity and induction problem; choice of theory and exact change; realism; scientific explanation; to experiment; measurement and quantification; evidence and basis for statistics; science based on actual data; experimental values are the central, fundamental debates in the philosophy of science. Understanding scientific objectivity is, therefore, essential to understanding the nature of science and its role in society. Under the concept of product objectivity, science is objective, or to such an extent that its products-theories, laws, experimental results, and observations-represent an accurate representation of the outside world. According to the understanding of the objectivity of the process, science is objective, or to such an extent that its necessary procedures and methods depend on the associated social and ethical values, the bias of the individual scientist. In particular, this second understanding is independently multi-faceted; and it includes explanations related to measurement procedures, self-justification processes, or socio-scientific scales.

The latter projects are characterized by high investment, long construction, and sophisticated technology. Many decision-making problems arise from imperfect information. This means that not all the information needed to create a reasonable solution is known [4]. In a market where customers reach balance, and product developers should have detailed information about product features, it is necessary to understand the importance of asymmetric information so that nobility, whether this inefficiency should cause concern, and when the degree of asymmetry is economically essential. Information asymmetry is usually greatest in areas where information is complex, difficult to obtain, or both [5]. Besides, asymmetric information is typical of a problem where the party has more information than the other and this is quite problematic. Insufficient information makes market problems more difficult. However, stakeholders also have incentives to create mechanisms that allow them to form mutually beneficial decisions even in the face of imperfect information [6-17]. The degree of asymmetry is different, yielding testable implications for the prevalence of asymmetric learning. In such a personal situation, decision-making is optional, using compensation data [18]. People practice multifaceted engineering solutions. Therefore, they should acknowledge a critical parameter corresponding to the degree to which the information is asymmetric. Humans implement multi-faceted decisions of engineers in practice [19-25]. Humans necessarily fill all measurement in science and technology with subjective elements, whether in selecting measures or in collecting, analyzing or interpreting data. Symmetric and asymmetric information play a critical role in engineering problems.

In Kant's view, all knowledge begins with human experience and is concurrent with the experience. The need for qualitative multi-criteria evaluation caused this-information content is determined by by the inexact scale of measurement [26]. The main problem, however, is dealing with qualitative information. Many methods consider qualitative data as pseudo-metric data, but officially forbid it as a way to consider qualitative details. Qualitative multi-criteria methods, in general, have to be survivable from the classification of the actual data. The lack of information in a multi-criteria analysis may emerge from two sources: 1) an imprecise definition of alternatives, evaluation criteria and preferences (or preference scenarios); and 2) an inaccurate measurement of the effects of other options on evaluation criteria and preference weights. One symmetry description is to say that it is the result of a balanced proportion harmony. There is a symmetrical balance when all the parts of the objects are well-balanced [27]. The perfect Yin Yang symbol is a sign of balance, harmony, and moderation. It is all about finding unity amidst duality (Figure 1). 


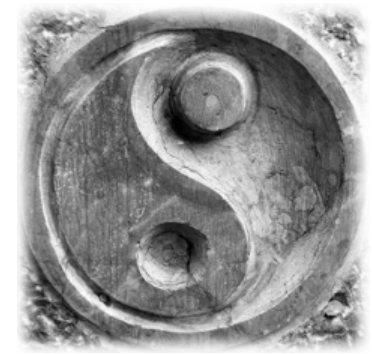

Figure 1. The Yin Yang symbol.

Scientists have proposed many strategies to improve the profitability of industries and apply sustainable production methods [28]. The evolution of design has highlighted the advantages of the principle of symmetry [29]. The balance in humans' duty affects such product conditions as structural efficiency, attractiveness, and economic, and functional or aesthetic requirements. It includes compliance with standardization requirements, production of repeat elements and mass production that reduces production costs [30]. Therefore, symmetry and regularity are generally reliable and symmetrical shapes are preferred but not asymmetric [31].

Besides the methodological developments, there are a large number of successful applications of multiple-criteria decision-making (MCDM) methods to real-world problems that have made MCDM a domain of great interest both for academics and for industry practitioners [32]. Often, different MCDM techniques do not lead to the same results. Multi-criteria utility models are models designed to obtain the utility of items or alternatives that are evaluated according to more than one criterion.

The most popular hybrid MCDM methods demonstrate the advantages over traditional ones for solving complicated problems, which involve stakeholder preferences, interconnected or contradictory criteria, uncertain environment. Decision-makers could use MCDM methods [33] such as the analytic hierarchy process [34], fuzzy analytic hierarchy process [35], fuzzy Delphi [36], analytic network process under intuitionistic fuzzy set [37], additive ratio assessment (ARAS) [38], simple additive weighting, and game theory [39], Discrete two persons' zero-sum matrix game theory [40], evaluation based on distance from average solution (EDAS), complex proportional assessment (COPRAS), technique for order preference by similarity to ideal solution (TOPSIS) [41], as well as develop original models [42]. Decisions made in complex contexts need these methods for practical solutions. Many studies proved the fact that construction materials contribute to sustainable building management [43,44].

The primary features on which depend the effectiveness of a project's life cycle [45] are a selection of proper place [46] and time to implement a plan [47], and to select a decent contractor [48].

The researchers directed to the hybrid MCDM approaches. The right knowledge for supporting systematic improvements evolution of the hybrid MCDM approaches can be characterized by $[49,50]$.

When decision-makers disagree, analysis of decisions can help to understand the situation of each person better, raise awareness of the issues involved and the cause of any conflict. Such improved communication and understanding can be of particular value when a team of professionals from different disciplines meets to make a decision. The analysis of decisions allows various stakeholders to participate in the decision-making process. It is the basis of a common understanding of the problem and makes is more likely that there will be a commitment to ultimately chosen action.

Keeney [51] pointed out that modern decision analysis does not create an optimal solution to the problem; the results of the study can be considered relatively prescriptive. The report shows the decision-maker what he should do, based on the decisions made during his analysis [52]. The central premise is rationality. When the decision-maker adopts rules or axioms that most people consider reasonable, he should give preference to the way they choose alternatives. The actions prescribed in the analysis may contradict the intuitive feelings of the decision-maker. He can then analyze this conflict of analysis and intuition. The study allows the decision-maker to understand the problem better so that his or her preference changes match the analysis priorities. This explains why the reasoned opportunity presented in the analysis is different from the natural choice of the decision-maker. 


\section{Contributions}

Nine original research articles are published in the current Special Issue. Authors from four continents contribute to the papers: Europe, Asia, South America and Africa (Figure 2). Three intercontinental papers are published: two articles co-authored by European and Asian researchers and one document involving European and African co-authors.

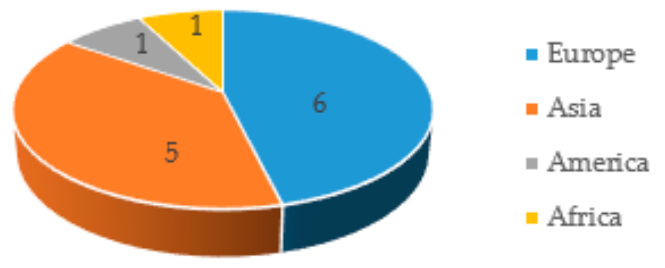

Figure 2. Distribution of papers by countries.

Thirty-seven authors from eight countries contributed to the Issue (Figure 3). The most numerous contributions are from Lithuania, China, Iran, and Romania. Moreover, we received submissions contributed by authors from Bosnia and Herzegovina, Serbia, Brazil, and Libya.

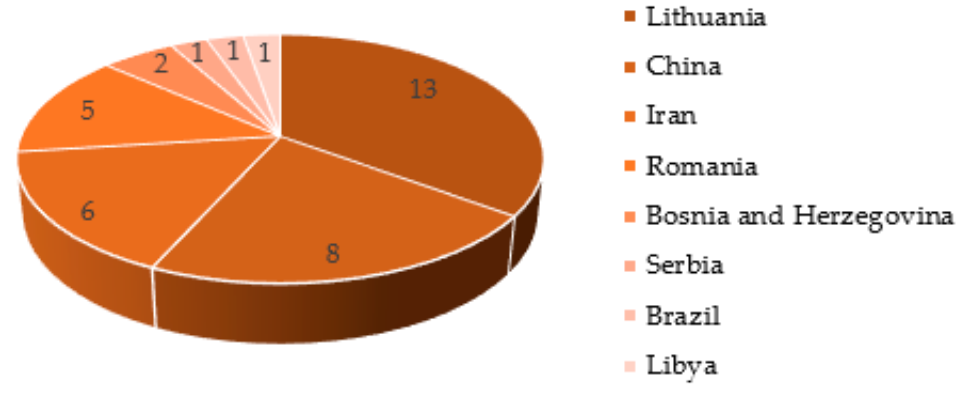

Figure 3. Distribution of authors by countries.

The delivery of papers according to authors' affiliations is presented in Table 1. Co-authors from Lithuania contribute to two papers together with co-authors from China and by one document with Iran, also with Serbia, Bosnia, and Herzegovina, and Libya. The other research teams are not international, and they involve authors from Brazil, Romania, China, Iran, and Lithuania.

Table 1. Publications by countries.

\begin{tabular}{cc}
\hline Countries & Number of Papers \\
\hline Brazil & 1 \\
Romania & 1 \\
China & 1 \\
Iran & 1 \\
Lithuania & 1 \\
China-Lithuania & 2 \\
Iran-Lithuania & 1 \\
Bosnia and Herzegovina-Serbia-Libya-Lithuania & 1 \\
\hline
\end{tabular}

All the papers suggest solution models based on symmetric or asymmetric information and they contribute to decision-making in various fields of engineering, economy or management. Most of the proposed models include novel or extended MCDM methods under uncertainty. Usual MCDM methods are combined with interval-valued fuzzy sets, rough numbers or Z-numbers. Only one-third of papers published in the current issue does not apply MCDM methods. They contribute to problems related to symmetry by offering other solution models like Bernoulli's binary sequences, repeated experiments or financial models (Figure 4). 


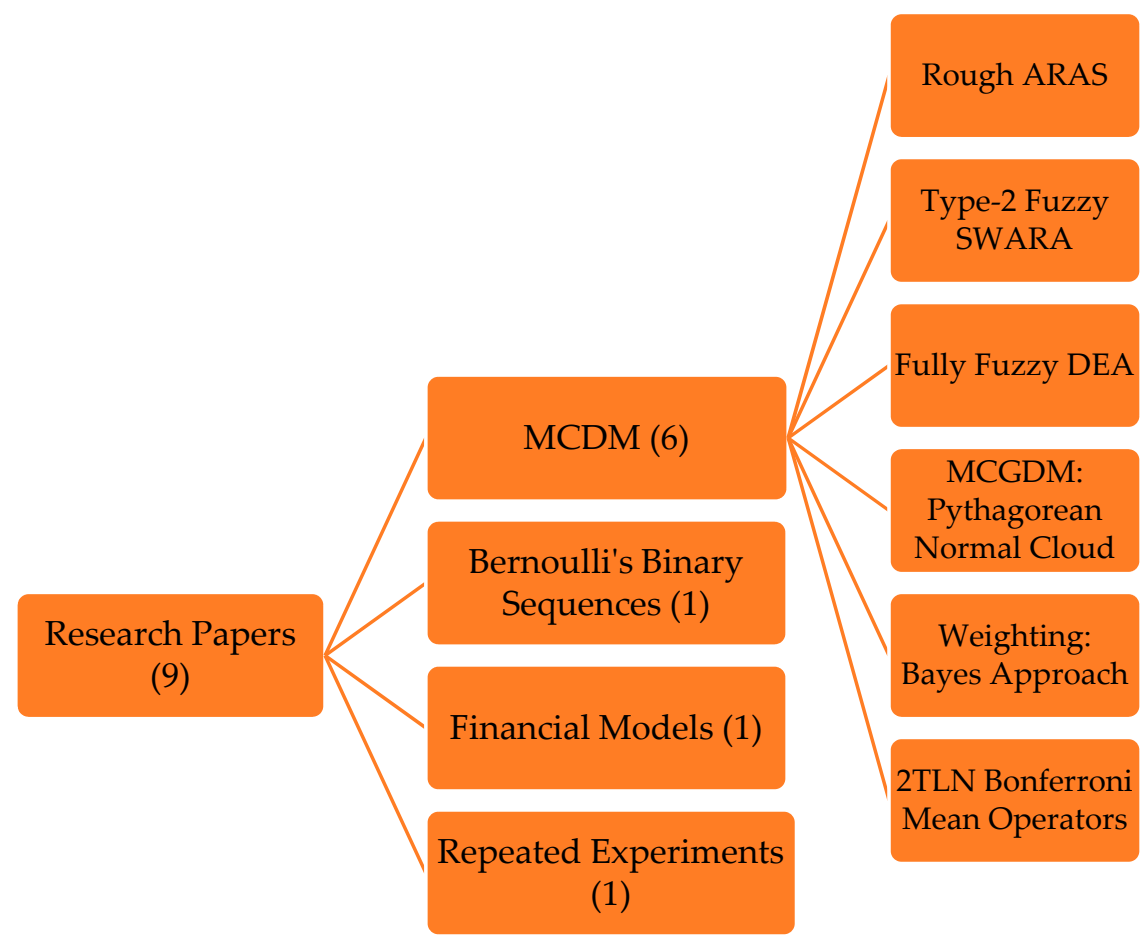

Figure 4. Applied decision-making approaches.

The presented case studies applying the proposed solution models dealing with symmetric or asymmetric information in the technological, economy or managerial problems are grouped into three research areas consisting of $2-4$ papers each (Figure 5).
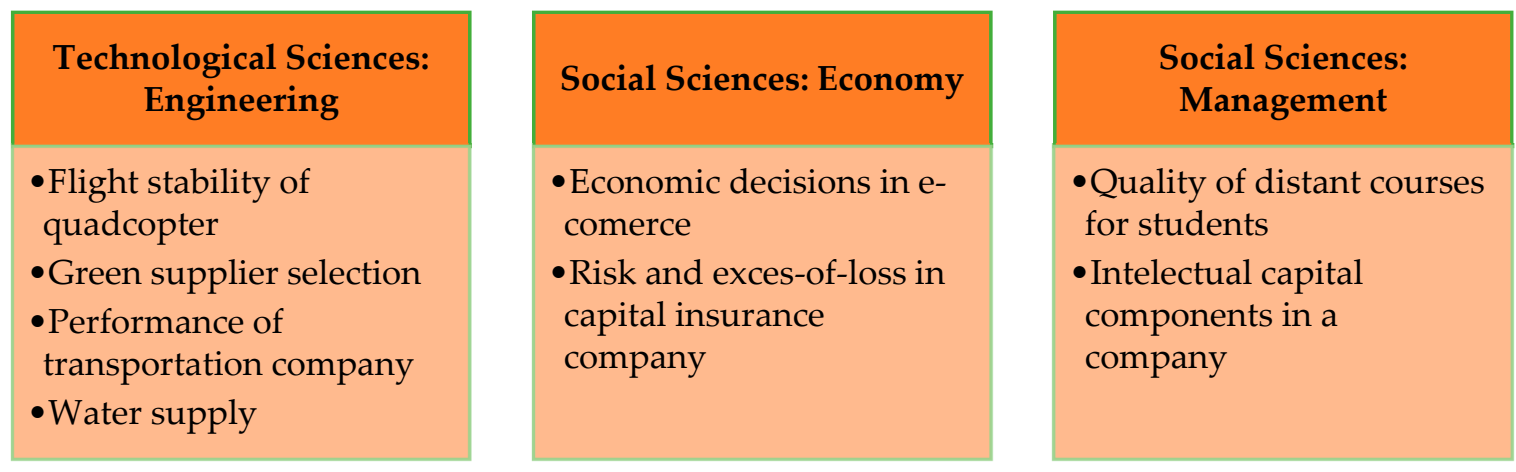

Figure 5. Research areas of the presented case studies.

Grouping of the papers in three research areas as presented in Figure 5 is rather conditional. In many of the research works, the fields are interrelated. The first paper explores water usage by analyzing Bernoulli's binary sequences in the representation of empirical events [53]. The analysis is also related to the economic problem of water usage-expenditure systems.

The next paper analyses the performance of transportation companies [54]. A novel multi-criteria rough ARAS model is developed in the paper. It is applied to companies' evaluation in developing countries. Sensitivity analysis is performed as well as comparison with other methods based on rough numbers is provided. The suggested approach will be further applicable for solving different problems.

Solving the efficiency evaluation with fuzzy data is also analyzed in another paper. The paper presents a new method for solving the fully fuzzy DEA (data envelopment analysis) model where all parameters are Z-numbers [55]. 
The topic of data fuzziness is continued in the paper aimed at the weighting of criteria in multi-criteria decision models [56]. An extended SWARA (step-wise weight assessment ratio analysis) method with symmetric interval type-2 fuzzy sets for determining the weights of criteria is developed. In the current paper, the suggested approach is applied for importance evaluation of intellectual capital components in a company.

One more paper aimed at the evaluation of weights of criteria proposes use of a Bayes approach for weight recalculation [2]. The core idea of the article is to suggest a plan for combining of criteria weights obtained by different subjective and objective criteria weight assessment methods.

Continuing a topic of data fuzziness, an emerging tool for uncertain data processing, that is known as neutrosophic sets, is applied. Several 2-Tuple linguistic neutrosophic number Bonferroni mean operators are developed [57]. They are applied in models for a currently topical issue of green supplier selection.

The approach partly resembling the TOPSIS (technique for order preference by similarity to ideal solution) method because of considering the symmetry of distances to the positive and the negative ideal solutions, and based on the Pythagorean normal cloud is proposed [58]. Moreover, some cloud aggregation operators are presented. The proposed approach is designated to economic decisions, and an example from e-commerce is presented.

The next paper related to economic decisions does not apply MCDM methods. It suggests financial models for optimal dividend and capital gains problem [59]. A reinsurance case with excessive losses based on risk information is presented.

The last paper representing the field of technological sciences and engineering, analyses symmetrically structured quadcopter and its flight stability [60]. The research focuses on developing a data logger and then applying repeated experiments.

After the above short presentation of research, we encourage the readers to undertake a detailed analysis of the papers published in the Special Issue.

\section{Conclusions}

The Guest Editors are very happy that the topics of the Special Issue generated interest among researchers from four Continents: Europa, Asia, South America, and Africa. Researchers from eight countries, including three international collectives, contributed to the papers published in the issue.

As could be expected concerning the aforementioned topics, multiple-criteria decision-making models are suggested in two-thirds of the papers. The authors of six articles (from nine articles published) apply MCDM methods in their research. Therefore, we can conclude that multiple-criteria decision-making techniques proved to be well applicable to symmetric information modeling.

Most approaches suggested decision models under uncertainty, combining the usual MCDM methods with interval-valued fuzzy or rough sets theory, also $\mathrm{Z}$ numbers.

The application fields of the proposed models involved both problems of technological sciences and social sciences. The papers cover three essential areas: engineering, economy, and management.

Author Contributions: All authors contributed equally to this work.

Acknowledgments: The authors express their gratitude to the journal Symmetry for offering an academic platform for researchers to contribute and exchange their recent findings in civil engineering and symmetry.

Conflicts of Interest: The authors declare no conflict of interest.

\section{References}

1. Turskis, Z.; Urbonas, K.; Daniūnas, A. A Hybrid Fuzzy Group Multi-Criteria Assessment of Structural Solutions of the Symmetric Frame Alternatives. Symmetry 2019, 11, 261. [CrossRef]

2. Vinogradova, I.; Podvezko, V.; Zavadskas, E.K. The Recalculation of the Weights of Criteria in MCDM Methods Using the Bayes Approach. Symmetry 2018, 10, 205. [CrossRef] 
3. Schad, J.; Lewis, M.W.; Raisch, S.; Smith, W.K. Paradox research in management science: Looking back to move forward. Acad. Manag. Ann. 2016, 10, 5-64. [CrossRef]

4. Zavadskas, E.K.; Turskis, Z.; Antucheviciene, J. Selecting a contractor by using a novel method for multiple attribute analysis: Weighted Aggregated Sum Product Assessment with grey values (WASPAS-G). Stud. Inform. Control 2015, 24, 141-150. [CrossRef]

5. Chalekaee, A.; Turskis, Z.; Khanzadi, M.; Ghodrati Amiri, G.; Keršulienè, V. A New Hybrid MCDM Model with Grey Numbers for the Construction Delay Change Response Problem. Sustainability 2019, 11, 776. [CrossRef]

6. Mardani, A.; Zavadskas, E.K.; Khalifah, Z.; Jusoh, A.; Nor, K. Multiple criteria decision-making techniques in transportation systems: A systematic review of the state of the art literature. Transport 2016, 31, 359-385. [CrossRef]

7. Mardani, A.; Jusoh, A.; Zavadskas, E.K. Fuzzy multiple criteria decision-making techniques and applications-Two decades review from 1994 to 2014. Expert Syst. Appl. 2015, 42, 4126-4148. [CrossRef]

8. Kahraman, C.; Onar, S.C.; Oztaysi, B. Fuzzy Multicriteria Decision-Making: A Literature Review. Int. J. Comput. Intell. Syst. 2015, 8, 637-666. [CrossRef]

9. Mardani, A.; Jusoh, A.; Nor, K.M.D.; Khalifah, Z.; Zakwan, N.; Valipour, A. Multiple criteria decision-making techniques and their applications-A review of the literature from 2000 to 2014. Econ. Res.-Ekon. Istraz. 2015, 28, 516-571. [CrossRef]

10. Antucheviciene, J.; Kala, Z.; Marzouk, M.; Vaidogas, E.R. Solving Civil Engineering Problems by Means of Fuzzy and Stochastic MCDM Methods: Current State and Future Research. Math. Probl. Eng. 2015, 2015, 362579. [CrossRef]

11. Keshavarz Ghorabaee, M.; Amiri, M.; Zavadskas, E.K.; Antucheviciene, J. Supplier evaluation and selection in fuzzy environments: A review of MADM approaches. Econ. Res.-Ekon. Istraz. 2017, 30, 1073-1118. [CrossRef]

12. Mardani, A.; Nilashi, M.; Antucheviciene, J.; Tavana, M.; Bausys, R.; Ibrahim, O. Recent fuzzy generalisations of rough sets theory: A systematic review and methodological critique of the literature. Complexity 2017, 1608147. [CrossRef]

13. Yazdanbakhsh, O.; Dick, S. A systematic review of complex fuzzy sets and logic. Fuzzy Sets Syst. 2018, 338, 1-22. [CrossRef]

14. Rajab, S.; Sharma, V. A review on the applications of neuro-fuzzy systems in business. Artif. Intell. Rev. 2018, 49, 481-510. [CrossRef]

15. Khan, M.; Son, L.H.; Ali, M.; Chau, H.T.M.; Na, N.T.N.; Smarandache, F. Systematic review of decision making algorithms in extended neutrosophic sets. Symmetry 2018, 10, 314. [CrossRef]

16. Mardani, A.; Nilashi, M.; Zavadskas, E.K.; Awang, S.R.; Zare, H.; Jamal, N.M. Decision making methods based on fuzzy aggregation operators: Three decades review from 1986 to 2017. Int. J. Inf. Technol. Decis. Mak. 2018, 17, 391-466. [CrossRef]

17. Turskis, Z.; Dzitac, S.; Stankiuviene, A.; Šukys, R. A Fuzzy Group Decision-making Model for Determining the Most Influential Persons in the Sustainable Prevention of Accidents in the Construction SMEs. Int. J. Comput. Commun. Control 2019, 14, 90-106. [CrossRef]

18. Govindan, K.; Rajendran, S.; Sarkis, J.; Murugesan, P. Multi criteria decision making approaches for green supplier evaluation and selection: A literature review. J. Clean Prod. 2015, 98, 66-83. [CrossRef]

19. Mardani, A.; Jusoh, A.; Zavadskas, E.K.; Khalifah, Z.; Nor, K.M. Application of multiple-criteria decisionmaking techniques and approaches to evaluating of service quality: A systematic review of the literature. J. Bus. Econ. Manag. 2015, 16, 1034-1068. [CrossRef]

20. Shen, K.Y.; Zavadskas, E.K.; Tzeng, G.H. Updated discussions on "Hybrid multiple criteria decision-making methods: A review of applications for sustainability issues". Econ. Res.-Ekon. Istraz. 2018, 31, 1437-1452. [CrossRef]

21. Govindan, K.; Hasanagic, M. A systematic review on drivers, barriers, and practices towards circular economy: A supply chain perspective. Int. J. Prod. Res. 2018, 56, 278-311. [CrossRef]

22. Govindan, K.; Soleimani, H. A review of reverse logistics and closed-loop supply chains: A Journal of Cleaner Production focus. J. Clean. Prod. 2017, 142, 371-384. [CrossRef]

23. Correia, E.; Carvalho, H.; Azevedo, S.G.; Govindan, K. Maturity models in supply chain sustainability: A systematic literature review. Sustainability 2017, 9, 64. [CrossRef] 
24. Mardani, A.; Jusoh, A.; Zavadskas, E.K.; Kazemilari, M.; Ahmad, U.N.U.; Khalifah, Z. Application of multiple criteria decision making techniques in tourism and hospitality industry: A systematic review. Transform. Bus. Econ. 2016, 15, 192-213.

25. Keshavarz Ghorabaee, M.K.; Zavadskas, E.K.; Amiri, M.; Turskis, Z. Extended EDAS method for fuzzy multi-criteria decision-making: An application to supplier selection. Int. J. Comput. Commun. Control 2016, 11, 358-371. [CrossRef]

26. Khanzadi, M.; Turskis, Z.; Ghodrati Amiri, G.; Chalekaee, A. A model of discrete zero-sum two-person matrix games with grey numbers to solve dispute resolution problems in construction. J. Civ. Eng. Manag. 2017, 23, 824-835. [CrossRef]

27. Hashemkhani Zolfani, S.; Zavadskas, E.K.; Turskis, Z. Design of products with both International and Local perspectives based on Yin-Yang balance theory and SWARA method. Econ. Res. -Ekon. Istraživanja 2013, 26, 153-166. [CrossRef]

28. Ruzgys, A.; Volvačiovas, R.; Ignatavičius, Č.; Turskis, Z. Integrated evaluation of external wall insulation in residential buildings using SWARA-TODIM MCDM method. J. Civ. Eng. Manag. 2014, 20, 103-110. [CrossRef]

29. Sousa, J.P.; Xavier, J.P. Symmetry-based generative design and fabrication: A teaching experiment. Autom. Constr. 2015, 51, 113-123. [CrossRef]

30. Jaganathan, S.; Nesan, L.J.; Ibrahim, R.; Mohammad, A.H. Integrated design approach for improving architectural forms in industrialized building systems. Front. Archit. Res. 2013, 2, 377-386. [CrossRef]

31. Banginwar, R.S.; Vyawahare, M.R.; Modani, P.O. Effect of plans configurations on the seismic behaviour of the structure by response spectrum method. Int. J. Eng. Res. Appl. 2012, 2, 1439-1443.

32. Balali, V.; Zahraie, B.; Roozbahani, A. A Comparison of AHP and PROMETHEE Family Decision Making Methods for Selection of Building Structural System. Am. J. Civ. Eng. Archit. 2014, 2, 149-159. [CrossRef]

33. Ye, K.; Zeng, D.; Wong, J. Competition rule of the multi-criteria approach: What contractors in China really want? J. Civ. Eng. Manag. 2018, 24, 155-166. [CrossRef]

34. De la Fuente, A.; Armengou, J.; Pons, O.; Aguado, A. Multi-criteria decision-making model for assessing the sustainability index of wind-turbine support systems: Application to a new precast concrete alternative. J. Civ. Eng. Manag. 2017, 23, 194-203. [CrossRef]

35. Prascevic, N.; Prascevic, Z. Application of fuzzy AHP for ranking and selection of alternatives in construction project management. J. Civ. Eng. Manag. 2017, 23, 1123-1135. [CrossRef]

36. Chen, C.J.; Juan, Y.K.; Hsu, Y.H. Developing a systematic approach to evaluate and predict building service life. J. Civ. Eng. Manag. 2017, 23, 890-901. [CrossRef]

37. Shariati, S.; Abedi, M.; Saedi, A.; Yazdani-Chamzini, A.; Tamošaitienè, J.; Šaparauskas, J.; Stupak, S. Critical factors of the application of nanotechnology in construction industry by using ANP technique under fuzzy intuitionistic environment. J. Civ. Eng. Manag. 2017, 23, 914-925. [CrossRef]

38. Štreimikienè, D.; Šliogerienè, J.; Turskis, Z. Multi-criteria analysis of electricity generation technologies in Lithuania. Renew. Energy 2016, 85, 148-156. [CrossRef]

39. Kalibatas, D.; Kovaitis, V. Selecting the most effective alternative of waterproofing membranes for multifunctional inverted flat roofs. J. Civ. Eng. Manag. 2017, 23, 650-660. [CrossRef]

40. Gardziejczyk, W.; Zabicki, P. Normalization and variant assessment methods in selection of road alignment variants-case study. J. Civ. Eng. Manag. 2017, 23, 510-523. [CrossRef]

41. Bielinskas, V.; Burinskienè, M.; Podviezko, A. Choice of abandoned territories conversion scenario according to MCDA methods. J. Civ. Eng. Manag. 2018, 24, 79-92. [CrossRef]

42. Keshavarz Ghorabaee, M.; Zavadskas, E.K.; Olfat, L.; Turskis, Z. Multi-criteria inventory classification using a new method of evaluation based on distance from average solution (EDAS). Informatica 2015, 26, 435-451. [CrossRef]

43. Giama, E.; Papadopoulos, A.M. Assessment tools for the environmental evaluation of concrete, plaster and brick elements production. J. Clean. Prod. 2015, 99, 75-85. [CrossRef]

44. Van Kesteren, I.E.H. Product designers' information needs in materials selection. Mater. Des. 2008, 29, 133-145. [CrossRef]

45. Shen, L.; Tam, V.W.Y.; Tam, L.; Ji, Y. Project feasibility study: The key to successful implementation of sustainable and socially responsible construction management practice. J. Clean. Prod. 2010, 18, 254-259. [CrossRef] 
46. Zavadskas, E.K.; Turskis, Z.; Bagočius, V. Multi-criteria selection of a deep-water port in the Eastern Baltic Sea. Appl. Soft Comput. 2015, 26, 180-192. [CrossRef]

47. Dahooie, J.H.; Zavadskas, E.K.; Abolhasani, M.; Vanaki, A.; Turskis, Z. A novel approach for evaluation of projects using an Interval-Valued Fuzzy Additive Ratio Assessment (ARAS) Method: A case study of oil and gas well drilling projects. Symmetry 2018, 10, 45. [CrossRef]

48. Hashemi, H.; Mousavi, S.M.; Zavadskas, E.K.; Chalekaee, A.; Turskis, Z. A New group decision model based on grey-intuitionistic fuzzy-ELECTRE and VIKOR for contractor assessment problem. Sustainability 2018, 10, 1635. [CrossRef]

49. Zavadskas, E.K.; Antucheviciene, J.; Turskis, Z.; Adeli, H. Hybrid multiple-criteria decision-making methods: A review of applications in engineering. Sci. Iran. 2016, 23, 1-20.

50. Zavadskas, E.K.; Govindan, K.; Antucheviciene, J.; Turskis, Z. Hybrid multiple criteria decision-making methods: A review of applications for sustainability issues. Econ. Res.-Ekon. Istraz. 2016, 29, 857-887. [CrossRef]

51. Keeney, R.L. Decision Analysis: An Overview. Oper. Res. 1982, 30, 803-838.

52. Phillips, L.D. Decision Analysis in the 1990's. In Tutorial Papers in Operational Research; Shahini, A., Stainton, R., Eds.; Operational Research Society: Birmingham, UK, 1989.

53. Telles, R.C. Geometrical Information Flow Regulated by Time Lengths: An Initial Approach. Symmetry 2018, 10, 645. [CrossRef]

54. Radović, D.; Stević, Ž.; Pamučar, D.; Zavadskas, E.K.; Badi, I.; Antuchevičiene, J.; Turskis, Z. Measuring Performance in Transportation Companies in Developing Countries: A Novel Rough ARAS Model. Symmetry 2018, 10, 434. [CrossRef]

55. Namakin, A.; Najafi, S.E.; Fallah, M.; Javadi, M. A New Evaluation for Solving the Fully Fuzzy Data Envelopment Analysis with Z-Numbers. Symmetry 2018, 10, 384. [CrossRef]

56. Keshavarz-Ghorabaee, M.; Amiri, M.; Zavadskas, E.K.; Turskis, Z.; Antucheviciene, J. An Extended Step-Wise Weight Assessment Ratio Analysis with Symmetric Interval Type-2 Fuzzy Sets for Determining the Subjective Weights of Criteria in Multi-Criteria Decision-Making Problems. Symmetry 2018, 10, 91. [CrossRef]

57. Wang, J.; Wei, G.; Wei, Y. Models for Green Supplier Selection with Some 2-Tuple Linguistic Neutrosophic Number Bonferroni Mean Operators. Symmetry 2018, 10, 131. [CrossRef]

58. Zhou, J.; Su, W.; Baležentis, T.; Streimikiene, D. Multiple Criteria Group Decision-Making Considering Symmetry with Regards to the Positive and Negative Ideal Solutions via the Pythagorean Normal Cloud Model for Application to Economic Decisions. Symmetry 2018, 10, 140. [CrossRef]

59. Yan, Q.; Yang, L.; Baležentis, T.; Streimikiene, D.; Qin, C. Optimal Dividend and Capital Injection Problem with Transaction Cost and Salvage Value: The Case of Excess-of-Loss Reinsurance Based on the Symmetry of Risk Information. Symmetry 2018, 10, 276. [CrossRef]

60. Kuantama, E.; Tarca, I.; Dzitac, S.; Dzitac, I.; Tarca, R. Flight Stability Analysis of a Symmetrically-Structured Quadcopter Based on Thrust Data Logger Information. Symmetry 2018, 10, 291. [CrossRef] 